\title{
Understanding Marcel Proust's Law of Desire
}

Brody SMITH

Il n'y a que le désir et du social et rien d'autre.'

lthough best known as the magician of involuntary memory, Marcel Proust (1871-1922) also boasts a significant critical and 1 literary contribution to the development of queer theory and scholarship in the epic, A la recherche du temps perdu. The third volume, Sodome et Gomorrhe, directly and at length explores for the first time in the Proustian opus the theme of male homosexual relations. The comedy of the overture introduces the concept of "la race des tantes," loosely translated as the "race of queens." Oddly enough, the genesis of this work began with the treatment of the abject homosexual in one of Proust's earlier works included in the collection of essays Contre Saint-Beuve. This ground-breaking excerpt bears the title of "La race maudite," in translation the "accursed race" and provides the genesis for "la race des tantes." The fusion of the two works reveals Proust's literary transformation of the abject and marginalized homosexual into an integrated member of Parisian bourgeois society at the end of the nineteenth century.

What exactly defines abjection and its relevance to this essay? According to Julia Kristeva, the economics of abjection invariably force an existence outside of oneself: "Inlassablement, comme un bommerang indomptable, un pôle d'appel et de répulsion met celui qui en est habité littéralement hors de lui." 2 Using the comparison of an inescapable 
boomerang, Kristeva portrays the subject unable to avoid the incessant torments of abjection that result in psychic instability and identification. Concordantly, Judith Butler defines and explicates related spatial complexities of abjection:

This exclusionary matrix by which subjects are formed thus requires the simultaneous production of a domain of abject beings...The abject designates here precisely those "unlivable" and "uninhabitable" zones of social life which are nevertheless densely populated by those who do not enjoy the status of subject, but whose living under the sign of the "unlivable" is required to circumscribe the domain of the subject. This zone of uninhabitability will constitute the defining limit of the subject's domain; it will constitute the site of the dreaded identification against which - and by virtue of which - the domain of the subject will circumscribe its own claim to autonomy and life. In this sense, then, the subject is constituted through the force of exclusion and abjection, one which produces a constitutive outside to the subject, an abjected outside, which is, after all, "inside" the subject as its own founding repudiation. ${ }^{3}$

By way of detailed explication, Butler interprets the complex zones marked by the abject subject's constitution. In concert, Kristeva and Butler set forth the interior and exterior quality and attributes of abjection, thereby pointing to a bifurcated existence. These dimensions provide indispensable frames of reference in order to better understand the stakes for the queer subject.

Although Proust's two literary works share a common homosexual subject, contradictions endure. For example, "La race maudite" depicts the solitary provincial life of the melancholic homosexual. On the other hand, the overture to Sodome et Gomorrhe recounts the comical observation of two Parisian men from different social classes, who, nonetheless, find a way to hook up. Abjection thus undergoes a metamorphosis. Repression yields to a world where alternative expressions of sexuality are governed by sheer desire. In other words, Proust's Utopia transcends any theory of uninhabitable zones and self-repudiation. Nor do social constructs limit access to sexual pleasure.

"La race maudite" prepares the reader for Sodom and Gomorrah. The Parisian aristocracy provides the backdrop for the encounter with the abject homosexual: the Marquis de Quercy. The narrator receives an invitation to the afternoon salon of the Prince and Princesse de Guermantes, who happen to be relatives of his neighbors, as well as relatives of the Marquis. Since the narrator belongs to the bourgeois class, Proust sets in motion 
an initial inversion of bourgeois versus aristocracy in order to illustrate tensions between the social classes of his time. Although the narrator frequents the local nobility, he still maintains his bourgeois status.

Prior to their meeting in the salon, the narrator has already noticed various details of the Marquis' routine through a voyeuristic gaze. From the vantage point of the window of his own apartment, he has seen the Marquis come and go from the Guermantes' residence. During the salon, the narrator introduces himself to the Marquis in a somewhat awkward fashion, yet no evident contact occurs. Nonetheless, the narrator knows he has been seen; thus, the gaze reverses. Subsequently, the Marquis retires, and the narrator begins a detailed account that will lead to a surprising discovery:

Pauvre M. de Quercy, qui aime tant la virilité, s'il savait l'air que je trouve à l'être las et souriant que j'ai devant moi. On dirait que c'est une femme! J'avais compris, c'en était une! C'en était une. ${ }^{4}$ Although the narrator names what he sees, these impressions create suspicions in the reader's mind as to the sexual orientation and gender of the Marquis, especially given the use of the feminine indefinite article "une." By actually articulating the description, the narrator confirms the definition. From his perspective, a homosexual is a woman, or better yet, a woman trapped in a man's body, thus complicating the assignment of any conventional gender marker.

At this point begins the description of the abject homosexual and his depraved lifestyle. Proust pens a famous sentence that extends over four pages. Therein, the rhetorical device of accumulation serves to bundle together ignominious traits and habits. The beginning of this section harkens back to the title of Proust's essay:

Race maudite puisque ce qui est pour elle l'idéal de la beauté et l'aliment du désir est aussi l'objet de la honte et la peur du châtiment, et qu'elle est obligée de vivre jusque sur les bancs du tribunal où elle vient comme accusée et devant le Christ. ${ }^{5}$

Through multiple binary oppositions, this passage portrays the existence of the homosexual as a complete lie. His desires do not align with acceptable social norms. Consequently, the homosexual is obliged to live on the margins, underscoring Butler's idea of zones of existence. In this case, the reprobate occupies a bench awaiting the judgment of Christ.

Furthermore, Proust substitutes conventional gendered pronouns with the neutral "it," thereby referring to a race or collective "it." To further. complicate matters, in French, the pronoun "elle" replaces la race. Thus, on numerous levels, language forces the lines of gender to be blurred. 
Traditional paradigms do not seem to function appropriately in this dimension. Yet Proust insists on ambiguity for a reason. The climax of the description of the abject character of the homosexual occurs toward the end of this section:

Car ses crimes peuvent être momentanés et chacun peut comprendre l'acte d'un voleur, d'un assassin mais non d'un homosexuel; partie donc réprouvée de l'humanité, mais membre pourtant essentiel, invisible, innombrable de la famille humaine." According to this passage, homosexuality defies comprehension and exceeds the potential consequences and punishments of theft and murder. Proust continues to emphasize the depiction of a hateful and outcast group. Anxiety enters the dynamic when conventional boundaries are crossed, thereby confusing social constructs and destabilizing traditional points of demarcation. Proust has already raised the level of ambiguity by referring to the Marquis de Quercy as a woman and a member of another race. However, the last words of the citation contradict previous denouncements. In spite of all their undesirable qualities, homosexuals remain essential members of the human race, invisible and too many to count.

Proust continues to manipulate conventional borders of gender and sexuality as he reflects on the challenge of fulfillment of homosexual desire:

Mais le plus souvent se contentant d'apparences grossières, et faute de trouver non pas l'homme-femme, mais la femme-homme qu'il leur faut, ils achètent d'un homme des faveurs de femme, ou par illusion dont le plaisir finit par embellir ceux qui le procurent, trouvent quelque charme viril aux êtres tout efféminés qui les aiment. ${ }^{\text {? }}$

In other words, the homosexual must be satisfied by exaggeration and never achieve what he ultimately desires. The fantasy or the mirage of the homosexual denotes a longing for sexual union with the masculine. Proust posits that a masculine woman fails to satisfy, while the effeminate man only serves as a surrogate. The physical attributes of an effeminate man allow the homosexual to play out the fantasy of a sexual encounter or relationship with the masculine during the ephemeral literal and figurative jouissance.

The end of the essay returns to the specific plight of the provincial life of the Marquis de Quercy. The reader learns that the Marquis had adolescent homosexual relations with his cousin who later marries. Now twenty-five years old, the Marquis relocates to Paris. The narrator describes him as an "Andromède attachée à un sexe pour lequel il n'était point 
fait." Succinctly put, male genitalia prevent true sexual orientation and encumber its expression. The Marquis appears to resign himself to these limitations through marriage to a woman:

Il s'éprit d'une fille de haute naissance qu'il épousa et pendant quinze ans ses désirs furent tous contenus dans le désir d'elle, comme une eau profonde dans une piscine azurée.

In order to function in his cultural and social location, the Marquis transfers his latent desires for another man by marrying a woman of his own social status. For fifteen years, his true desires were contained in his desire for his wife. The binary of the river and the pool suggests the convergence of two different bodies, a metaphor for the exceedingly difficult task of managing such a complicated identity. Once again, we find ourselves in a different zone of existence. The narrator further relates that the Marquis reverts to his former sexual proclivities, "mais sa situation le préservait un peu." 10 The Marquis' social standing provides little advantage and does not completely protect him. This comment further illustrates the erasure of conventional class boundaries.

On the other hand, in Sodome et Gomorrhe, auto-homophobia undergoes a transformation. Proust therein creates a world which valorizes the acceptance and social integration of the homosexual. The overture begins with an epigraph taken from the poem "La colère de Samson" by Alfred de Vigny: "La femme aura Gomorrhe et l'homme aura Sodome." " Proust thus appropriates the theme of homosexuality from another published literary work in order to introduce his own agenda. Alfred de Vigny projects his personal anxiety over suspicions that his current female companion may have a secret sexual alliance with another woman. He denounces this relationship in the quotation. In effect, Proust introduces the topic indirectly through resistance and containment: A taboo issue surfaces but, at the same time, is managed so as not to go too far. For the time being, the homosexual is metaphorically contained in an abject biblical and historical space.

In Sodome et Gomorrhe, the hesitancy of Proust to take on this forbidden subject parallels that of the narrator. The Marquis de Quercy from "La race des tantes" undergoes a metamorphosis and becomes the Baron de Charlus. In the opening paragraph, the reader is prepared for what is to come:

[...] j'avais épié leur retour et fait, pendant la durée de mon guet, une découverte, concernant particulièrement $M$. de Charlus, mais si importante en elle-même que j'ai jusqu'ici, jusqu'au moment de pouvoir lui donner la place et l'étendue voulues, différé de la rapporter. ${ }^{12}$ 
Proust, the voyeur, engages us yet again. "It" does not presently have a name. In the Proustian sphere, the exposition of the subject of homosexuality requires adequate preparation, including procrastination and avoidance. The text arrives at an important revelation. As in the beginning of " $\mathrm{La}$ race maudite," the narrator observes without being seen. He witnesses the unplanned initial encounter of the Baron de Charlus with the family waistcoat maker, Jupien. Harkening back to "La race maudite," the narrator reacts to Charlus' appearance: "...c'était à une femme!"13 However, this description does not seem to conflict with Jupien's preferences:

M. de Charlus... avait recontré le giletier et avec lui la bonne fortune reservée aux hommes du genre du baron par un de ces êtres qui peuvent même être, on le verra, infiniment plus jeunes que Jupien et plus beaux, l'homme predestiné pour que ceux-ci aient leur part de volupté sur cette terre: l'homme qui n'aime que les vieux messieurs. ${ }^{14}$

This reference signals a rejection of abjection. Aristocracy now mingles with a family retainer. The opportunity of homosexual relations outside the extended family and social class breaks through and transgresses conventions but is again contained through secret trysts. There is even a particular subgroup of younger homosexual men that desire older men. Proust expands the homosexual community and allows it to blur another aspect of the social order in yet another inversion: elderly and youthful.

In fact, the narrator actually hears the sexual encounter between the two men:

Car d'après ce que j'entendis les premiers temps dans celle de Jupien et qui ne furent que des sons inarticulés, je suppose que peu de paroles furent prononcées. Il est vrai que ces sons étaient si violents que, s'il n'avaient pas été toujours repris un octave plus haut que par une plainte parallèle, j'aurais pu croire qu'une personne en égorgeait une autre à côté de moi et qu'ensuite le meurtrier et sa victime ressuscitée prenaient un bain pour effacer les traces du crime. J'en conclus plus tard qu'il y a une chose aussi bruyante que la souffrance, c'est le plaisir, surtout quand s'y ajoutent des soucis immédiats de propreté. ${ }^{\text {s }}$

This scene between Jupien and Charlus illustrates the daring nature of the narrative. The narrator experiences the encounter through a multiplicity of violent sounds of torture and pain without dialogue. Consequently, he draws a parallel between levels of loudness in both cries of suffering and pleasure. Of particular interest is the issue of cleanliness. This reference underscores both the shame associated with the sexual act and the neces- 
sary disposal of any physical evidence. Michel Foucault's commentary on historical sexual discourse resonates with the text:

Mais, au-delà de ces plaisirs troubles, elle revendiquait d'autres pouvoirs; elle se posait en instance souveraine des impératifs d'hygiène, ramassant les vieilles peurs du mal vénérien avec les themes nouveaux de l'asepsie... elle prétendait assurer la vigueur physique et la propreté morale du corps social. ${ }^{16}$

Concerning hygiene, Foucault relates the ever-present longstanding fears of venereal disease along with the new issues concerning asepsis. He also circumscribes the need to ensure physical vigor and the moral propriety of society through cleanliness. Charlus and Jupien take Foucault a step further. They must safeguard their secret. To that end, a bath proves necessary.

Without doubt, Proust remained exceedingly concerned about the public's reaction to this text. In his biography of Marcel Proust, William C. Carter asserts: "Proust wanted to prepare readers and critics for the opening pages of Sodome et Gomorrhe."17 He even requested the critical opinion of the French novelist, François Mauriac, a devout Catholic. Mauriac's response proves evasive at best: "The examination of one's conscience is the basis of all moral life, and Proust projects a terrible light on our inner depths."18 Whether or not he intended to do so, Mauriac infers that a closeted homosexual lives inside every person. Perhaps he did not fully comprehend the text. Clearly, Proust becomes the architect of a new literary space which threatens conventional understandings of gender and sexuality, for earlier Honoré de Balzac could only hint at Vautrin's desire for Lucien de Rubempré at the very end of Les Illusions perdues and throughout Splendeurs et misères des courtisanes.

The author continues to reappropriate the abject experiences of the Marquis de Quercy by describing the hook up of two men of different classes and age groups. Comedy enters the dialogue with the description of the courtship between Jupien and the Baron de Charlus:

Or Jupien, perdant aussitôt l'air humble et bon que j'avais toujours connu, avait - en symétrie parfaite avec le baron redressé la tête, donnait à sa taille un port avantageux, posait avec une impertinence grotesque son poing sur la hanche, faisait saillir son derrière...Je ne savais pas qu'il pût avoir l'air si antipathique. ${ }^{19}$

Similar to a species of exotic birds, Jupien and the Baron perform an exaggerated seduction dance that will lead to their conjunction. Jupien, the principal actor, throws his head back, puts his wrist on his hip and sticks out his behind. Proust accents the hilarity with the following comment 
regarding this spectacle, which he likens to a theatrical performance: "Cette scène n'était, du reste, pas positivement comique." ${ }^{20}$ Through the use of the rhetorical device of negation the reader understands how truly comical the antics appear. After their tryst, and during the course of a volley of sarcastic exchanges, Jupien informs the Baron de Charlus: "Vous en avez un gros petard!"21 Why is this particular exclamation funny? Walter Benjamin provides a response by defining the quality of Proustian comedy in $A$ la recherche du temps perdu:

In the treasury of its prejudices and maxims there is not one that is not annihilated by a dangerous comic element... His style is comedy, not humor, his laughter does not toss the world up but flings it down - at the risk that it will be smashed to pieces... And unity of family and personality, of sexual morality and professional honor, are indeed smashed to bits. The pretensions of the bourgeoisie are shattered by laughter. Their return and reassimilation by the aristocracy is the sociological theme of the work. ${ }^{22}$

Benjamin accurately describes the Jupien/Charlus encounter. The potential scandal of social transgressions cannot escape Proust's wit. Through his daring, he literally shatters conventions and norms. Benjamin further states: "The reader of Proust is constantly jarred by small shocks." ${ }^{23}$ Levity thus opens the mind of the reader concerning the behavior of homosexuals and their pervasive existence in society - a wonderful example of comic relief.

Proust, master of French syntax, again composes a string of modifiers that continue over the space of approximately four pages of the text. Yet here the tone differs. Homosexuals still constitute a race apart, but they are no longer regarded as thieves and murderers. The form a secret association that Proust likens to freemasons, except that homosexuals are more efficient and less suspect than ordinary lodge members:

[...] car elle repose sur une identité de goûts, de besoins, d'habitudes, de dangers, d'apprentissage, de savoir, de trafic, de glossaire, et dans laquelle les membres souhaitent de ne pas se connaître, aussitôt se reconnaissent à des signes naturels ou de convention, involontaires ou voulus. ${ }^{24}$

In this passage, the narrator compiles a list of attributes that bring this group together, consisting in an identity that functions on a variety of levels, not all of which are determined by the individual. While they may have common interests and tastes, they also come together in danger situations, the newcomers learning the trade - literally and figuratively - from the 
more experienced, thus assuring the continuation of the species. They share a special lexicon that allows them to communicate without being understood by the uninitiated. However, we return to the theme of selfrepudiation of "La race des tantes" when the narrator states that irrespective of common ground, they do not want to know one another. Nonetheless, recognition comes through means that cannot be controlled or measured. Their identity reflects self-loathing and repulsion. Paradoxically, these aversions also extend to members of their confrérie.

Arguing from a historical perspective, Michel Foucault states that a homosexual identity and subculture were invented at the end of the nineteenth century:

Il ne faut pas oublier que la catégorie psychologique, psychiatrique, médicale de l'homosexualité s'est constituée un jour où on l'a caractérisée - le fameux article de Westphal en 1870 , sur les "sensations sexuelles contraires" peut valoir comme date de naissance - moins par un type de relations sexuelles, une certaine manière d'intervenir en soi-même le masculin et le féminin. L'homosexualité est apparue comme une des figures de la sexualité lorsqu'elle a été rabattue de la pratique de la sodomie sur une sorte d'androgynie intérieure, un hermaphrodisme de l'âme. Le sodomite était un relaps, l'homosexuel est maintenant une espèce. ${ }^{25}$

Foucault defines homosexuality not initially based on sexual relations but rather as the individual's interior sorting out of male and female identities, such as hermaphrodism. Furthermore, homosexuality acquired its sexual connotations with the advent of sodomy identified with internal gender associations, or the lack thereof. In other words, the economics of sexual desire can resist containment only to a certain point. Homosexuals henceforth constitute a species, a circumscription that resonates with Proust's race maudite.

At the end of the thirty-two page overture, the narrator now expands the homosexual community to a global status:

Certes il forment dans tous les pays une colonie orientale, cultivée, musicienne, médisante, qui a des qualités charmantes et d'insupportable défauts. On les verra d'une façon plus approfondie au cours des pages qui suivront; mais on a voulu provisoirement prévenir l'erreur funeste qui consisterait, de même qu'on a encouragé à créer un mouvement sodomiste et à rebâtir Sodome. ${ }^{26}$ To begin with, the narrator continues to portray paradox between the erudition and the sarcasm of the homosexual. By way of this provocative 
and sardonic statement, Proust in his own manner allows the homosexual subject to enter the public domain again through resistance and containment: They are charming but mean and are found everywhere. Textually, he purposely delays revealing too much too soon, so as not to provoke the reaction that he may be encouraging a membership drive of sorts, literally calling for the formation of a movement of Sodomists with the intention of rebuilding Sodom. This negative depiction continues to draw criticism. For example, André Gide publicly denounced Proust's attempt to render the material elusive. More recently, in Homos, Leo Bersani attempts to reduce the depiction of the Proustian gay community to a bitchy and essentially heterosexual text, without fully understanding the complicated nuances and historicity of Proust's homosexual subject. Another odd treatment can be found in Joseph Litvak's Strange Gourmets, where the author tries to build a case for the primacy of the homosexual's intelligence and arrogance. While these traits certainly exist, such a monochromatic approach belies the overarching complexity of Proust's evolutionary text.

Similar nuances, related to the destabilization of conventional gender markers, are addressed in a more sophisticated manner in the next sequence. In "La race maudite," the narrator proposes the idea of the homosexual as a woman trapped inside the body of a man. Proust now further develops this image by describing an effeminate young man waking up in bed:

Quelques-uns, si on les surprend le matin, encore couchés, montrent une admirable tête de femme, tant l'expression est générale et symbolise tout le sexe; les cheveux eux-mêmes l'affirment; leur inflexion est si féminine, déroulés, ils tombent si naturellement en tresses sur la joue, qu'on s'émerveille que la jeune femme, la jeune fille, Galatée qui s'éveille à peine dans l'inconscient de ce corps d'homme où elle est enfermée. ${ }^{27}$

Initially, the text points to the element of surprise required of the voyeuristic gaze in order to witness this seemingly natural phenomenon. We then continue with the identifying elements of face and hair, which, according to the narrator, symbolize the female sex in its entirety. In particular, the movement of the hair frames the face in a manner to render it feminine, causing the onlooker to marvel at the awakening of the unconscious Galatea held captive in a man's body. The central idea of this passage finds a parallel in the novel Monsieur Vénus by the French author Rachilde. Written in 1883, Monsieur Vénus tackles the reversal of conventional sexual roles. Rachilde employs the template of the woman-man and the man-woman to confuse conventional ideas of gender. Evidently, the liter- 
ary preoccupation concerning a way to transcend traditional sexual markers predates Proust. At the same time, the wealth of scholarship dedicated to gender studies and sexuality underscores the fact that we continue to seek to deconstruct related social norms and conventions.

To further complicate matters, Proust refers to the "la ruse apparente des fleurs," ${ }^{28}$ wherein he comments on the manner in which nature governs reproduction in order to control and ensure continuation of the species. $\mathrm{He}$ extends the same concept to humans by comparing this idea to the manner in which the body responds to certain stresses. For example, fatigue follows too much pleasure. Flowers and insects explain the natural quality of the sexual encounters of the characters in Sodome et Gomorrhe, but at the same time they serve as a reminder of the need to avoid excess. However, the genesis of Proust's theory occurs in "La race maudite." The Marquis de Quercy, according to the observations of the narrator, always wears a boutonnière. When the narrator decides to attend the salon of the Guermantes, he decides to imitate the Marquis:

Je voulais me commander une boutonnière chez le fleuriste mais ma grand-mère trouvait qu'une rose de jardin serait plus 'naturelle.' Après avoir marché sur un massif en pente et en piquant mon habit aux épines des autres, je coupai la plus belle, et je sautai dans l'omnibus qui passait devant la porte...le parfum montait invisible...comme un secret d'amour. Et quand j'arrivai au moment d'entrer...j'étais pris dans le flot et ne pouvais plus rien faire, distrait d'ailleurs par la nécessité d'avoir à enlever mon pardessus, prendre un numéro, jeter ma rose qui s'était déchirée sous mon paletot et dont l'immense tige verte était tout de même trop 'naturelle.'29

Proust takes great care to valorize the natural quality of picking a rose from the garden rather than buying one from a florist. The flower is thus taken with some difficulty from the rosebush in a garden rather than acquired through a purchase or exchange of commodities. The scent of the rose is invisible and intoxicating, able to attract an insect, or vehicle, for pollination - a metaphor for sexual relations. Yet the flower possesses a fragile constitution, indicating the delicacy of desire in its myriad of expressions. When hidden, as the rose beneath the overcoat, desire cannot thrive. The enormous green stalk represents the phallic power that remains visible even after the petals of the flower are detached, which the narrator finds too natural, referring to the degree in which he is caught up in popular social conventions, all the more evident since he manages to keep company with a social class above his own. 
Returning to Sodome et Gomorrhe, Proust again invokes nature in order to bolster his hypothesis of the sexual encounter occurring outside the economics of nature and conventional moral order:

Comme tant de créatures du règne animal et du règne végétal, comme la plante qui produirait la vanille, mais qui, parce que, chez elle, l'organe mâle est séparé par une cloison de l'organe femelle, demeure stérile si les oiseaux-mouches ou certaines petites abeilles ne transportent le pollen des unes aux autres ou si l'homme ne les féconde artificiellement... (et ici le mot fécondation doit être pris au sens moral, puisque au sens physique l'union du mâle avec le mâle est stérile, mais il n'est pas indifférent qu'un individu puisse rencontrer le seul plaisir qu'il soit susceptible de goûter, et 'qu'ici-bas toute âme' puisse donner à quelqu'un 'sa musique, sa flamme ou son parfum'). ${ }^{30}$

This comparison between flowers and insects denotes the inherent complications of hooking up in both the plant and animal kingdoms. For example, the narrator gives the example of the orchid, a flower possessing both male and female sexual organs separated only by a partition. Yet the orchid depends upon birds or bees or artificial human interaction to ensure its pollination and reproduction. Parenthetically, almost as an aside or an afterthought, not meant to confuse the reader, Proust qualifies this type of fertilization from a moral perspective. In other words, in the physical sense the union of two males does not yield progeny. Yet these natural laws do not exclude the possibility of transgression driven by desire. Here the text suggests that pleasure can be experienced outside any established boundaries.

Conversely, we must now return to the beginning of the text to suture the dynamics of the pursuit of pleasure. The narrator therein launches a floral stratagem as a prelude to his observation of the Jupien/Charlus hook up:

Je savais que cette attente n'était pas plus passive que chez la fleur mâle, dont les étamines s'étaient spontanément tournées pour que l'insecte pût plus facilement le recevoir; de même la fleur femme qui était ici, si l'insecte venait, arquerait coquettement ses 'styles' et pour mieux être pénétrée par lui ferait imperceptiblement... la moitié du chemin. ${ }^{31}$

Both the male and female flowers actively respond to the advances of the pollinating insect. The male turns his stamens in order to receive, while the female extends herself in order to meet the insect. This cross-pollination provided by an external source ensures the survival of the species. This 
passage implies that the chance encounter of Charlus and Jupien serves to broaden and strengthen "la race maudite." The more this type of hook up takes place, the possibility of growth in numbers and the building of the community occurs.

In fact, the expansion of the community reaches its apotheosis in Le temps retrouvé, the final volume of $A$ la recherche du temps perdu. With the passage of time, the narrator and Jupien have matured, while Charlus appears as an elderly man whose sexual proclivities have reached new and greater heights. We find the narrator on his way home from an evening out with friends. However, he does not feel well and decides to find a hotel where he can rest a while and have a drink. What a surprise awaits his perpetual curiosity when he decides to check out the premises. He hears the sound of muffled cries in one of the rooms and decides to investigate. Placing his ear to the door, he hears the following exchange:

'Je vous en supplie, grâce, grâce, pitié, détachez-moi, ne me frappez pas si fort, disait une voix. Je vous baise les pieds, je m'humilie, je ne recommencerai pas. Ayez pitié. - Non, crapule, répondit une autre voix, et puisque tu gueules et que tu te traînes à genoux, on va t'attacher sur le lit, pas de pitié,' et j'entendis le bruit du claquement d'un martinet, probablement aiguisé de clous car il fut suivi de cris de douleur. ${ }^{32}$

This dialogue reveals two individuals in definite roles. One is being punished for some reason, and the other is administering discipline. While one voice pleads for mercy on his knees, the other refuses to desist and continues the torture while informing the suppliant that he is going to be tied to the bed because he is complaining and kneeling. The registers used indicate a relationship founded on power and submission. While the first voice uses the formal vous in sophisticated language, the second responds in a vulgar register and employs the familiar $t u$. Thus, the text already points to some type of derogation. The narrator remains within the discourse and comments on hearing the cracking of a whip, probably fortified with nails, followed by cries of pain. It is worth noting that during the late nineteenth and early twentieth centuries, the use of such instruments of discipline was common in convents and monasteries throughout Europe. Thought to quell the passions, the beatings were either administered by the individual or a confrere. Further along, Jupien indeed confirms his knowledge of this practice when he informs the narrator: "Ici, c'est le contraire des carmels, c'est grâce au vice que vit la vertu." ${ }^{33}$ Simply put, virtue exists due to vice and not the opposite. Such a commentary points to the reification of this practice, thus rendering it perverse rather than pious. 
Overtaken by inquisitiveness, the narrator finds a way to slip into the room unnoticed and beholds an impressive scene:

Enchaîné sur un lit comme Prométhée sur son rocher, recevant les coups d'un martinet en effet planté de clous qui lui infligeait Maurice, je vis, déjà tout en sang et couvert d'ecchymoses qui prouvaient que le supplice n'avait pas lieu pour la première fois, je vis devant moi M. de Charlus. ${ }^{34}$

Unlike his first aural experience of the Charlus/Jupien tryst, the narrator now observes Charlus during the act itself. Referring to Greek mythology, he compares Charlus to the hero Prometheus fettered to a rock and unable to escape, thus underscoring the aristocratic origins of the baron irrespective of the present circumstances which cause any social conventions to disintegrate. Already bloody, Charlus receives strikes from Maurice, a gigolo. The narrator notes that the baron is covered with bruises, indicating that this is not the first session he witnesses.

In the next section, the narrator sees Jupien enter the room to take control of the situation. After dismissing Maurice, Charlus expresses his doubts that the young man possesses the qualifications to function in the role of a master. Jupien reassures the baron in vain. Here the text reveals that the baron himself bought the hotel and hired Jupien to manage the operation behind the scenes and serving Charlus as a surrogate sex therapist. A sordid affair, we learn that the establishment is frequented by an array of clients, including a priest that the narrator initially mistakes for "une dame assez agée, en jupe noire," 35 showing a lack of respect for the clergy with the afterthought: "C'était cette chose si rare, et en France absolument exceptionnelle, qu'est un mauvais prêtre." 36 In other words, above all in France it would be an exception to find a bad priest. A perceived old woman in a black skirt seeking the services of a male brothel certainly does not represent virtue. Furthermore, when the priest forgets to pay, Jupien interjects: "Pour les frais de culte, monsieur l'abbé!" 37 The money taken covers the expenses of partaking of forbidden pleasures rather than the upkeep of a parish church. Finally, the narrator returns and adds: "Le vilain personnage s'excuse, donna sa pièce et disparut," now depicted as a depraved character who pays and then disappears. This passage constitutes an example of Proustian sarcasm at its best, squarely aimed at clerical hypocrisy, a prevalent public attitude at the time. After the baron leaves the premises, the narrator speaks at length with Jupien and expresses disgust of the operation: "C'est un vrai pandemonium." 39 Jupien responds with an invitation to the narrator to return and experience the ambiance, further destabilizing the social location. Dissolving the 
impassibility of any conventional boundaries through the Charlus/Jupien saga, Proust shows the fragility of sexuality and the power of desire.

From a more contemporary perspective, the French philosopher, writer, and gay activist Guy Hocquenghem articulates certain theoretical points which bolster Proust's positions and their relevance to current strands of queer scholarship. Published in 1972 following the events of May, 1968 and Stonewall, Hocquenghem's Le désir homosexuel offers a provocative analysis of desire. In the introduction to the most recent English edition, Michael Moon underscores the key to understanding this work:

[... the object of a given desire does not determine the 'nature' of that desire - that is, 'desire is desire,' to put it plainly, the apparent tautology intended to suggest that there is not some 'right desire,' heterosexual in nature, and some 'wrong' or 'misplaced' or 'perverted' one that is homosexual..$^{40}$

Clearly, pure desire defies any norms or markers related to morality, sexual orientation or gender: According to Hocquenghem, and following the theme treated by Proust, flowers and insects are not sexed. They are the machines of desire, thus creating a greater number of possibilities for plugging in.

In order to illustrate this point, Hocquenghem refers the Baron de Charlus and Jupien's complicated relationship:

De même tout se passe entre Charlus et Jupien sans nom. En vérité la machine de drague se moque bien des noms et des sexes. La dérive où toutes les rencontres deviennent possibles, c'est le moment où le désir produit sans culpabiliser. ${ }^{41}$

Hocquenghem relates that what passes between Charlus and Jupien has no name. This is particularly true in their first encounter. The cruising machine mocks taxonomy and sexual constructs. Moreover, the juncture where pleasure becomes possible refers to the moment in time when desire dominates without any feeling of guilt. This dynamic is transformed in the pages of Le Temps retrouvé, where pleasure equals pain and must be calculated, taking on the form of a simulacrum in the reproduction of a torture chamber.

In conclusion, "La race maudite," and selections from $A$ la recherche du temps perdu represent ground-breaking literary works that take on issues related to gender and sexuality that continue to challenge contemporary queer theory and scholarship. For example, the melancholic affect of Monsieur de Quercy, the seductive dance between Jupien and Charlus and the torture scene of the baron clearly reflect Judith Butler's ideas concerning gender performativity: 
$[\ldots]$ gender is performatively produced and compelled by the regulatory practices of gender coherence...gender proves to be performative - that is, constituting the identity it is purported to be. In this sense, gender is always a doing, though not by a subject who might be said to preexist the deed... There is no gender identity behind the expressions of gender; that identity is performatively constituted by the very "expressions" that are said to be its results. ${ }^{42}$

Decidedly, the constant marker that sutures Proust to Butler finds its valence in a particular performative context rather than any social construct. Whether through the abject affect of the Marquis de Quercy, the seduction dance of Charlus and Jupien, or the baron's self-designed torture chamber hidden in a hotel, Proust succeeds in dissolving the impassibility of any conventional boundaries. He shows the fragility of sexuality and the power of desire, while his sheer artistry blurs conventional linguistic gender markers. In sum, Proust deconstructs the heteronormative model. Indeed, following Hocquenghem's claim, desire will out.

\section{Notes}

1. Gilles Deleuze and Félix Guatarri, L'Anti-Oedipe (Paris: Minuit, 1972), 36.

2. Julia Kristeva, Pouvoirs de l'horreur (Paris: Editions du Seuil, 1980), 9.

3. Judith Butler, Bodies that Matter: On the Discursive Limits of "Sex" (New York: Routledge, 1993), 3.

4. Marcel Proust, "La race maudite" in Contre Sainte-Beuve (Paris: Editions Gallimard, 1954), 248-49.

5. Ibid, 249.

6. Ibid, 252.

7. Ibid, 254-55.

8. Ibid, 257-58.

9. Ibid, 260.

10. Ibid, 260.

11. Marcel Proust, Sodome et Gomorrhe (Paris: Éditions de la Pléiade, 1988), 3.

12. Ibid, 3.

13. Ibid, 6 .

14. Ibid, 9 .

15. Ibid, 11 . 
16. Michel Foucault, Histoire de la sexualité I (Paris: Editions Gallimard, 1980), 72-73.

17. William C. Carter, Marcel Proust, a Life (New Haven: Yale University Press, 2000), 743.

18. Ibid, 743.

19. Proust, Op. Cit., 6.

20. Ibid, 7

21. Ibid, 11

22. Walter Benjamin, "The Image of Proust," in Illuminations (New York: Shocken Books, 1985), 206-207.

23. Ibid, 208.

24. Ibid, 18.

25. Foucault, Op. Cit., 59.

26. Proust, Op. Cit., 33.

27. Ibid, 22.

28. Ibid, 5.

29. Proust, "La race des tantes," 243-44.

30. Proust, Sodome et Gomorrhe, 28.

31. Ibid, 4-5.

32. Marcel Proust, Le temps retrouvé (Paris: Éditions de la Pléiade, 1989), 394.

33. Ibid, 409.

34. Ibid, 394.

35. Ibid, 407.

36. Ibid, 407-408.

37. Ibid, 408.

38. Ibid, 408.

39. Ibid, 411.

40. Guy Hocquenghem, Homosexual Desire (Durham, North Carolina: Duke University Press, 1996), 17.

41. Guy Hocquenghem, Le désir homosexuel (Paris: Fayard, 2000), 150.

42. Judith Butler, "Subjects of Sex/Gender/Desire," in Gender Trouble (New York: Routledge, 1999), 25. 
